\title{
FOOD SECURITY AND REGIONAL AGRICULTURAL MARKET: ECONOMIC ANALYSIS AND DEVELOPMENT PROSPECTS
}

\author{
Marina Lescheva ${ }^{1}$, Anna Ivolga ${ }^{2}$
}

\begin{abstract}
Summary
The analysis of dynamics and current state of an agrifood market is conducted on the case of the agrarian region of Stavropol Krai. The research objective is to analyse development factors and tendencies of the regional agrifood market; to assess the import dependency rate of selected product sectors; to investigate the perspective directions of domestic market saturation. The research subject is a system of economic relations, directed on the establishment and development of the agricultural commodities and food market, and a range of special economic measures for insurance of the food security in the Russian Federation. The analysis includes the market capacity and level of self-sufficiency in the Stavropol Krai, which are defined by basic foodstuffs. It is found that people's needs in food are covered insufficiently. It is revealed that Stavropol Krai is an active player on both inter-regional and international markets, with the substantial amounts of counter deliveries. Agricultural raw commodities of low added value predominate in export, while processed ones of higher added value - in imports. Food processing industry of the region is underdeveloped, however, it has substantial reserves for development. The major protection measures of domestic food market are defined in the paper: diversification of agricultural production, and industrial and logistics infrastructure development of the regional agrarian market. The results can be used by regional government authorities in improving of the domestic food market regulations.
\end{abstract}

Key words: food security, agriculture, regional market, import, export, consumption, income of the population.

JEL: $Q 18, F 52$

1 Marina Lescheva, Ph.D., Professor of the Department of Economic Analysis and Audit, Stavropol State Agrarian University, 12, Zootekhnichesky Pereulok, 355017 Stavropol, Russia, Phone: +7 86 523559 80, E-mail: marina lesheva60@mail.ru

2 Anna Ivolga, Ph.D., Associate Professor of the Department of Tourism and Service, Stavropol State Agrarian University, 12, Zootekhnichesky Pereulok, 355017 Stavropol, Russia, Phone: +7 86523559 80, E-mail: annya iv@mail.ru

EP 2014 (61) 4 (877-893) 


\section{Introduction}

Providing the population with food in sufficient quantity and variety is a challenge, which includes a range of issues of food production, import dependence and export orientation of the food market, solvency and dietary patterns of the population.

Domestic production of basic agricultural commodities and food in many countries, including such big agricultural producers as Russia, fails to meet demand. Such countries have to rely on agricultural imports, leaving them vulnerable to global price fluctuations and impacting their export revenues, which tremendously threat food security of those nations (Serova, 2014).

Obviously, in the international realm, countries are different from each other that are why issues of food security have to be defined through the prism of national interest (Wegren, 2013). Despite the considerable amount of work carried out the issues of availability of food need to be updated, require adaptation to develop regional strategies for agricultural development to the specific conditions of the modern domestic food market, which determined the purpose and objectives of the present study (Giovannucci et al., 2012). In the domestic realm, the evidence about food security is mixed; the content of this issue is different to the one on the international level (Wegren, 2013).

The need to conduct it was enhanced due to the publication of the Decree of the President of the Russian Federation V. V. Putin "On the application of certain special economic measures to ensure the security of the Russian Federation" from 06.08.2014 (Decree №560, 2014), the Decree provides for restrictions on the importation into Russia of certain types of food from the United States, Canada, the EU, Australia and Norway for a period of one year. The rating of Russian regions depending on imported food and preparedness for renunciation becomes therefore of particular relevance.

This defines the purpose of the study - to analyse the factors shaping and state food market one of the largest Russian regions, to assess the degree of its dependence on imports of certain products and to identify the most promising areas of complete saturation.

\section{Material and Methods}

Investigations were carried out on the basis of dialectical, abstract-logical, comparative methods using the factor and correlation analysis of official statistical information, research data of scientific publications.

For the purposes of the current research, we have primarily addressed the works by Russian and foreign researches and experts. Demand management, agro-food products are considered in the works by Gajsin R. S. Factors affecting food security in the region, are described in the works by Siptic S. O., Romanenko I. A., Afanasiev E. V., Grigoriev N. V., Rudov E. V. There are a large number of publications on the organization of marketing research. The most significant of these include the publications by T. S. Bronnikov, E. P. Golubkova, F. I. Evdokimova, V. N. Eremina, E. M. Feoktistova and V. P. Hlustova. 
Special attention was paid to the investigations of the contemporary issues of food security in Russia, made by Wegren (2013), Serova (2014), Ivolga and Timofeeva (2014) and Savkin and Pervykh (2013). Effects of agricultural production on food security and vice versa are obtained from Jelocnik and Ivolga (2012), Kiselev et al. (2013) and Stringer (2000) and Ivolga (chapter "State Program for Development of Agriculture and its Contemporary Applications: Issues of Rural Development in Russia" in Erokhin et al, 2014, pp. 6983). Since food security is directly related to international trade in agricultural commodities and food, we have also addressed works of Josling et al. (2010) and Hailu (2010) in the sphere of trade in agricultural products between developed and developing countries; Erokhin et al. (2014) in the sphere of trade in agricultural products between developed and developing countries; Erokhin in the sphere of effects of trade liberalization and state support of agriculture for developing countries (chapter "Ensurance of Sustainable Rural Development through Liberalization of Trade with Agricultural Commodities and CAP Reforms" in Erokhin et al., 2014, pp. 49-68); Erokhin and Ivolga (2012) in the aspects of sustainable rural development through trade integration.

Data for the purposes of the current research had been obtained from the reports of the Territorial Body of the Russian Federal Service of State Statistics in Stavropol Krai (2013). The following state programs have been considered: State Program for Development of Agriculture and Markets of Agricultural Commodities, Raw Materials and Food for 20132020 (2012), and Doctrine of Food Security of the Russian Federation (2010).

\section{Results and Discussion}

The analysis was conducted on the case of Stavropol Krai. Agrarian sector is one of the leading ones in the regional economy. Agricultural production provides 10-15\% of the gross regional product (GRP), accumulates $13-16 \%$ of the total investment, and employs $17.3 \%$ of the domestic population.

The region has considerable land resources (the 8th place in the Russian Federation), it is characterized by high natural fertility of soils ( $47 \%$ of all land is black soil). More than 2 hectares of agricultural land and 1.4 hectares of arable land account per inhabitant of the Stavropol territory, which is higher than the Russian average and reflects one of the highest rates of land provision regions - agricultural producers. In conjunction with the availability of labour resources, rich historical experience and traditions of agricultural production and favourable bioclimatic conditions are characterized by considerable economic potential for the solution of not only regional but also the general federal objectives of improving food security and the provision of food.

Over the last decade, the importance of the region in the country's food security for most products is increasing (Table 1). Currently, the territory is a major producer of grain (9\% of Russia's gross harvest), sunflower (5\%), sugar beet $(4.8 \%)$ and wool (the 2nd place in the country). 
Table 1. Share of the Stavropol Krai in agricultural production of Russia (in \%)

\begin{tabular}{|l|r|r|}
\hline \multirow{2}{*}{\multicolumn{1}{|c|}{ Indicators }} & \multicolumn{2}{c|}{ On average for } \\
\cline { 2 - 3 } & $\mathbf{2 0 0 0} \mathbf{- 2 0 0 5}$ & $\mathbf{2 0 0 8} \mathbf{- 2 0 1 2}$ \\
\hline Agricultural products & 2.7 & 3.0 \\
\hline including: & 7.1 & 8.7 \\
\hline - grain & 3.0 & 4.8 \\
\hline - sugar beet & 5.9 & 5.1 \\
\hline - sunflower & 1.8 & 2.0 \\
\hline - milk & 2.7 & 2.8 \\
\hline - meat in carcass weight & 2.1 & 2.2 \\
\hline - eggs & 13.9 & 13.0 \\
\hline
\end{tabular}

Source: authors' development based on (Territorial Body of the Federal Service of State Statistics of the Russian Federation in Stavropol Krai, 2013)

After the recession of 1990s, agricultural production in the region has been growing. In the long-term retrospective output indices of agricultural products around the territory is above the Russia's average, but the sensitivity of the industry to changes in weather patterns in the Stavropol Krai is much higher. In the extremely dry 2010-2012, the gross crop production declined on $10 \%$ and $19 \%$ correspondingly. In this regard, the trend line reflects the low rates of positive development (Figure 1).

Figure 1. Output indices of agricultural production (farms of all categories of the Stavropol Krai, in comparable prices, \% of previous year)

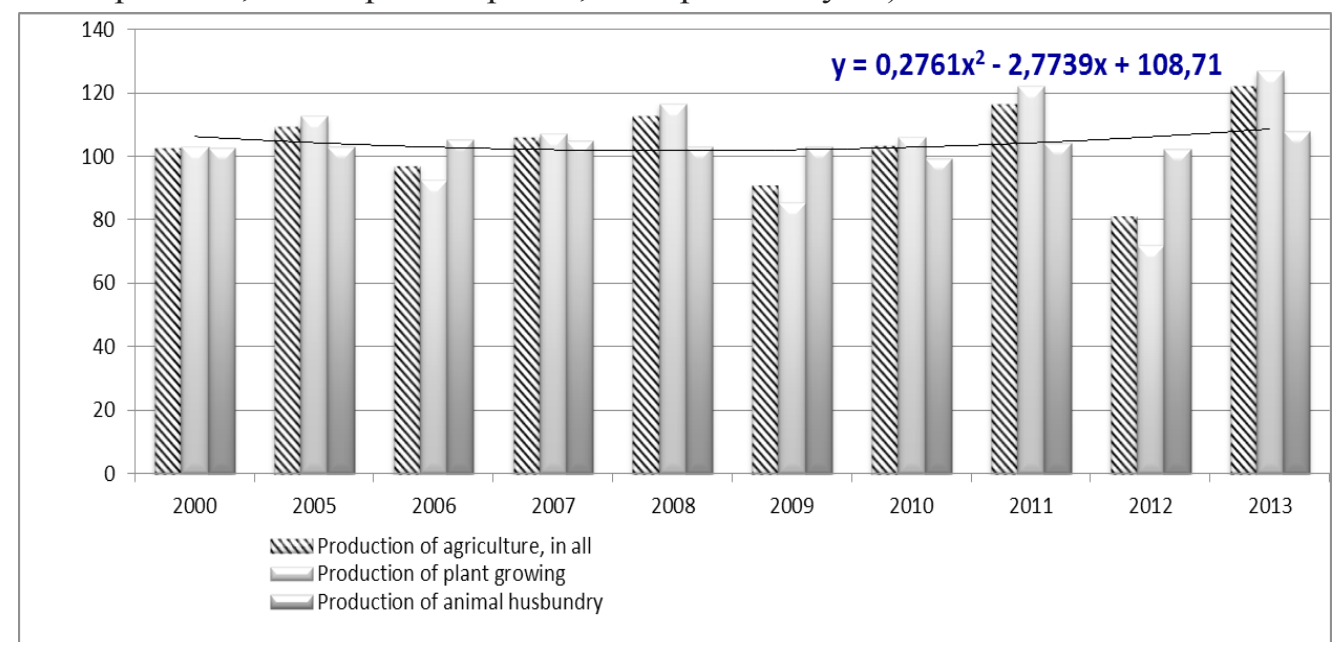

Source: authors' development

In order to identify patterns of modern development of the regional agrocultural and food market, the following major groups of agricultural productswere targeted: corn and its by-products; meat and meat products; milk and dairy products; potatoes; vegetables and food melons; fruits and berries; eggs and egg products; fish and fish products. 
The market capacity of listed products was determined by the production method according to the formula:

$\mathrm{C}=\mathrm{P}+\mathrm{V}_{\text {import }}-\mathrm{V}_{\text {export }}+\mathrm{V}_{\mathrm{d}}$

Where,

$\mathrm{P}$ - volume of production during the period,

$\mathrm{V}_{\text {import }}$ and $\mathrm{V}_{\text {export }}$ - values ofthe output in imports and exports correspondingly.

$\mathrm{V}_{\mathrm{d}}$ - amount of change in the volume of stocks at the beginning and end of the period.

The results of calculation are presented in the Table 2 suggesting that the increase in the Stavropol market capacity was observedfor all products, exept sugar.

Table 2. Capacity of the regional market in the context of product groups (in 000 tons)

\begin{tabular}{|l|c|c|c|c|c|c|}
\hline \multicolumn{1}{|c|}{ Product group } & $\mathbf{2 0 0 8}$ & $\mathbf{2 0 0 9}$ & $\mathbf{2 0 1 0}$ & $\mathbf{2 0 1 1}$ & $\mathbf{2 0 1 2}$ & $\begin{array}{c}\mathbf{2 0 1 2} \text { in } \\
\mathbf{2 0 0 8}\end{array}$ \\
\hline $\begin{array}{l}\text { Products of grain processing } \\
\text { (flour, cereals) }\end{array}$ & 394.3 & 402.4 & 405.6 & 409.0 & 415.2 & 105.3 \\
\hline Meat and meat products & 166.7 & 175.7 & 186.1 & 191.6 & 207.9 & 124.7 \\
\hline Milk and dairy products & 569.4 & 578.6 & 612.2 & 611.8 & 614.8 & 108.0 \\
\hline Potatoes & 399.0 & 413.0 & 413.7 & 426.2 & 441.7 & 110.7 \\
\hline Vegetables and melons food & 458.6 & 462.2 & 477.1 & 482.0 & 527.0 & 114.9 \\
\hline Fruits and berries & 138.0 & 136.2 & 150.1 & 149.2 & 142.4 & 103.2 \\
\hline Sugar & 148.4 & 136.2 & 152.7 & 153.5 & 140.4 & 94.6 \\
\hline Vegetable oil & 48.6 & 51.3 & 52.5 & 57.4 & 58.8 & 121.0 \\
\hline $\begin{array}{l}\text { Eggs and egg products mln. } \\
\text { pieces }\end{array}$ & 818.3 & 832.3 & 850.5 & 984.6 & 968.6 & 118.4 \\
\hline Fish and fish products & 18.7 & 20.0 & 21.7 & 22.3 & 25.1 & 134.2 \\
\hline
\end{tabular}

Source: authors' development based on (Territorial Body of the Federal Service of State Statistics of the Russian Federation in Stavropol Krai, 2013)

The most rapid market growth is characterized by meat and meat products (increase on $24.7 \%)$, vegetable oil (21\%), fish and fish products (34.2\%).

The relatively low world food prices, urbanization and rising incomes had contributed to the expansion of demand for these products, thereby stimulating the development of production and trade. The main source of the saturation of the regional food market is its own production. The dynamics of the main types of foodstuffs in the Stavropol region is presented in Table 3. It reflects the essential increase in output of almost commodity groups. 
Table 3. Production of basic food in the Stavropol Krai (in 000 tons)

\begin{tabular}{|c|c|c|c|c|c|c|}
\hline Product group & 2008 & 2009 & 2010 & 2011 & 2012 & $\begin{array}{l}2012 \text { in } \\
\% \text { to } 2008\end{array}$ \\
\hline $\begin{array}{l}\text { Products of grain processing } \\
\text { (flour, cereals) }\end{array}$ & 433.3 & 476.5 & 471.2 & 568.1 & 511.5 & 118.0 \\
\hline Meat and meat products & 178.9 & 190.1 & 189.0 & 207.9 & 225.2 & 125.9 \\
\hline Milk and dairy products & 611.2 & 624.0 & 633.7 & 664.7 & 665.3 & 108.9 \\
\hline Potatoes & 261.2 & 250.7 & 286.8 & 345.9 & 374.2 & 143.3 \\
\hline Vegetables and melons food & 275.1 & 270.8 & 335.1 & 399.5 & 517.5 & 188.1 \\
\hline Fruits and berries & 68.1 & 66.9 & 73.4 & 71.7 & 64.9 & 95.3 \\
\hline Sugar & 129.5 & 106.7 & 163.1 & 167.5 & 55.8 & 43.1 \\
\hline Vegetable oil & 56.2 & 72.0 & 44.6 & 55.4 & 69.9 & 124.4 \\
\hline Eggs and egg million. pieces & 817.0 & 823.6 & 885.9 & 884.4 & 817.2 & 100.0 \\
\hline Fish and fish products & 5.0 & 5.2 & 5.8 & 5.8 & 6.7 & 134.0 \\
\hline
\end{tabular}

Source: Territorial Body of the Federal Service of State Statistics of the Russian Federation in Stavropol Krai, 2013

During the past five-year period the production of vegetables has increased by $88 \%, 43 \%-$ potatoes, $25 \%$ - meat and meat products, $24 \%$ - of vegetable oil. However, the production capacity of agriculture implemented the region is not fully utilized.

The pre-reform line of 1990 for some individual products has not reached yet. So, in 2013, the beef production was only $25 \%$, pork - by $34 \%$, milk by $36 \%$, eggs - by $72 \%$ below 1990 levels. The resource generation of meat, milk, eggs, vegetables and fruits is realizing mainly due to private farms at present. The absence of large-scale production capacity constrains the rate of gross yield of agricultural raw materials and food market saturation. The dynamics of the level of self-sufficiency of the Stavropol Krai food is presented in Figure 2. It was calculated as the ratio of the own output to consumption. 
Figure 2. Level of self-sufficiency of basic foodstuffs in Stavropol Krai

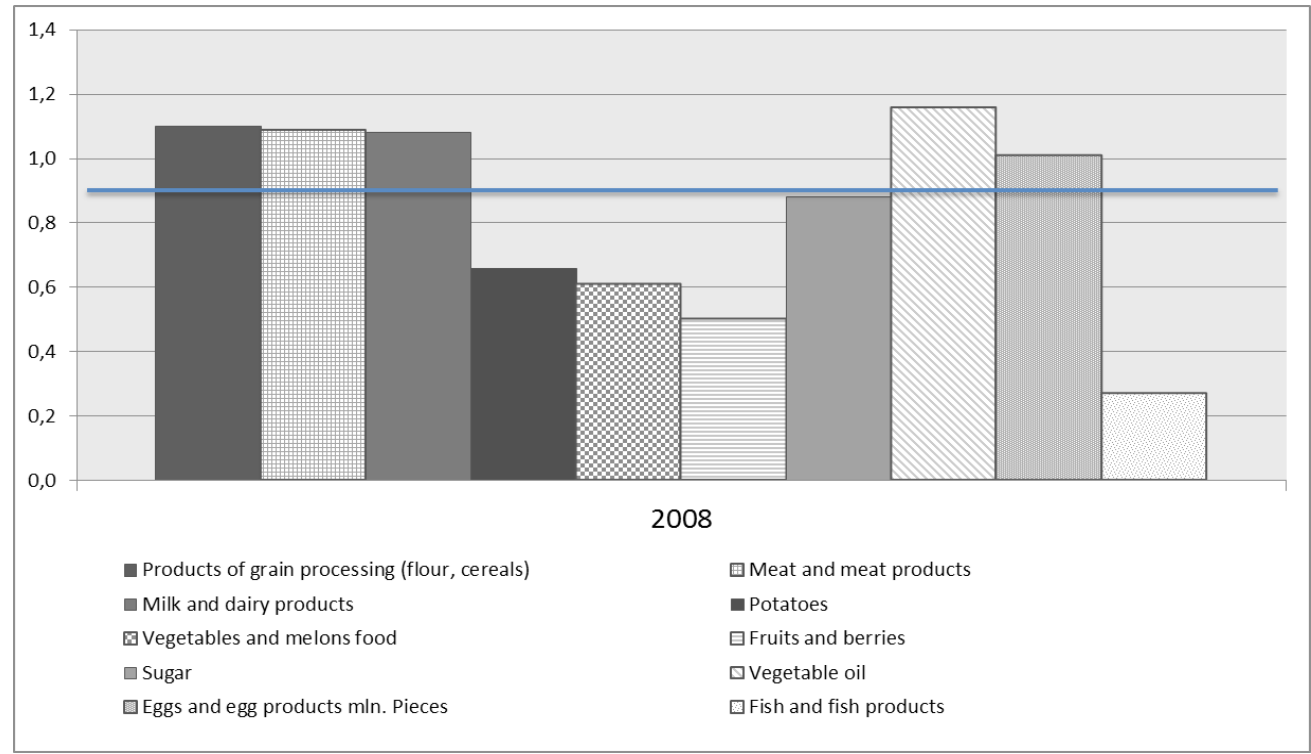

Source: authors' development based on (Territorial Body of the Federal Service of State Statistics of the Russian Federation in Stavropol Krai, 2012)

The data show that Stavropol region can provide the domestic consumption of refined products of grain, meat, milk, and vegetable oil. The index of self-sufficiency for these types of products is above1. Local production does not cover domestic needs in such products as potatoes, vegetables, eggs, fruits and berries, fish, and sugar.

Table 4. Dynamics of imports and exports of agricultural products and foodstuffs in the Stavropol territory

\begin{tabular}{|l|c|c|c|c|c|c|}
\hline \multicolumn{1}{|c|}{ Product group } & $\mathbf{U M}$ & $\mathbf{2 0 0 8}$ & $\mathbf{2 0 0 9}$ & $\mathbf{2 0 1 0}$ & $\mathbf{2 0 1 1}$ & $\mathbf{2 0 1 2}$ \\
\hline $\begin{array}{l}\text { Products of grain processing (flour, cereals): } \\
\text { import }\end{array}$ & $\begin{array}{c}\text { thous. } \\
\text { tons }\end{array}$ & 242.6 & 250.9 & 162.9 & 449.9 & 55.0 \\
\hline $\begin{array}{l}\text { Products of grain processing (flour, cereals): } \\
\text { export }\end{array}$ & $\begin{array}{c}\text { thous. } \\
\text { tons }\end{array}$ & 282.6 & 323.7 & 221.6 & 604.9 & 160.3 \\
\hline Meat: import & $\begin{array}{c}\text { thous. } \\
\text { tons }\end{array}$ & 39.0 & 31.1 & 40.1 & 40.0 & 120.7 \\
\hline Meat: export & $\begin{array}{c}\text { thous. } \\
\text { tons }\end{array}$ & 48.7 & 46.3 & 41.4 & 56.8 & 138.9 \\
\hline Milk and dairy products: import & $\begin{array}{c}\text { thous. } \\
\text { tons }\end{array}$ & 20.2 & 33.7 & 41.4 & 30.5 & 30.1 \\
\hline Milk and dairy products: export & $\begin{array}{c}\text { thous. } \\
\text { tons }\end{array}$ & 63.7 & 79.7 & 63.8 & 83.2 & 77.9 \\
\hline Potatoes: import & $\begin{array}{c}\text { thous. } \\
\text { tons }\end{array}$ & 143.8 & 161.7 & 99.3 & 111.3 & 89.0 \\
\hline Potatoes: export & $\begin{array}{c}\text { thous. } \\
\text { tons }\end{array}$ & 0.0 & 0.0 & 0.0 & 3.1 & 7.7 \\
\hline
\end{tabular}




\begin{tabular}{|l|c|c|c|c|c|c|}
\hline \multicolumn{1}{|c|}{ Product group } & $\mathbf{U M}$ & $\mathbf{2 0 0 8}$ & $\mathbf{2 0 0 9}$ & $\mathbf{2 0 1 0}$ & $\mathbf{2 0 1 1}$ & $\mathbf{2 0 1 2}$ \\
\hline Vegetables and melons food: import & $\begin{array}{c}\text { thous. } \\
\text { tons }\end{array}$ & 199.5 & 210.3 & 162.1 & 199.2 & 119.4 \\
\hline Vegetables and melons food: export & $\begin{array}{c}\text { thous. } \\
\text { tons }\end{array}$ & 8.2 & 28.9 & 15.4 & 95.9 & 104.3 \\
\hline Fruit and berries: import & $\begin{array}{c}\text { thous. } \\
\text { tons }\end{array}$ & 72.6 & 71.7 & 83.5 & 80.3 & 78.7 \\
\hline Fruit and berries: export & $\begin{array}{c}\text { thous. } \\
\text { tons }\end{array}$ & 4.0 & 2.8 & 3.2 & 2.2 & 1.7 \\
\hline Sugar: import & $\begin{array}{c}\text { thous. } \\
\text { tons }\end{array}$ & 154.7 & 159.1 & 152.5 & 158.0 & 121.4 \\
\hline Sugar: export & $\begin{array}{c}\text { thous. } \\
\text { tons }\end{array}$ & 131.7 & 129.8 & 169.9 & 148.2 & 76.6 \\
\hline Vegetable oil: import & $\begin{array}{c}\text { thous. } \\
\text { tons }\end{array}$ & 92.9 & 87.9 & 79.4 & 72.7 & 80.9 \\
\hline Vegetable oil: export & $\begin{array}{c}\text { thous. } \\
\text { tons }\end{array}$ & 101.6 & 105.4 & 49.0 & 97.3 & 91.3 \\
\hline Eggs and egg products: import & $\begin{array}{c}\text { mln. } \\
\text { pcs }\end{array}$ & 120.2 & 101.8 & 64.2 & 184.8 & 245.4 \\
\hline Eggs and egg products: export & $\begin{array}{c}\text { mln. } \\
\text { pcs }\end{array}$ & 118.2 & 92.5 & 98.9 & 90.7 & 90.9 \\
\hline Fish and fish products: import & $\begin{array}{c}\text { thous. } \\
\text { tons }\end{array}$ & 13.9 & 14.7 & 16.8 & 17.3 & 19.6 \\
\hline Fish and fish products: export & $\begin{array}{c}\text { thous. } \\
\text { tons }\end{array}$ & 0.1 & 0.4 & 0.5 & 0.5 & 0.6 \\
\hline
\end{tabular}

Source: Territorial Body of the Federal Service of State Statistics of the Russian Federation in Stavropol Krai, 2013

Stavropol Krai is deeply integrated into the inter-regional and international markets. Majority of agricultural products and food comes to the regional market from other regions of Russia, as well as from the CIS and other foreign countries. Region is supplied with vegetables and fruit produced in neighbouring areas with more favourable conditions for their production (Krasnodar Territory, the Republic of Dagestan, the Republic of North Ossetia-Alania, Volgograd region, etc.), China, Israel, and Europe. Eggs come from Nizhny Novgorod and Rostov regions, Krasnodar and Perm territories, the Republic of Tatarstan. Milk and dairy products, meat and meat products, other food are imported from Krasnodar Territory, Rostov region, Republic of Karachaevo - Cherkessia, Republic of Belarus, EU countries, Baltic States, China, Israel and other countries. The balance of export and import of basic food groups is presented in Figure 3. 
Figure 3. Balance of export and import of food products according to the regional statistics department of the Stavropol Krai (in 000 tons)

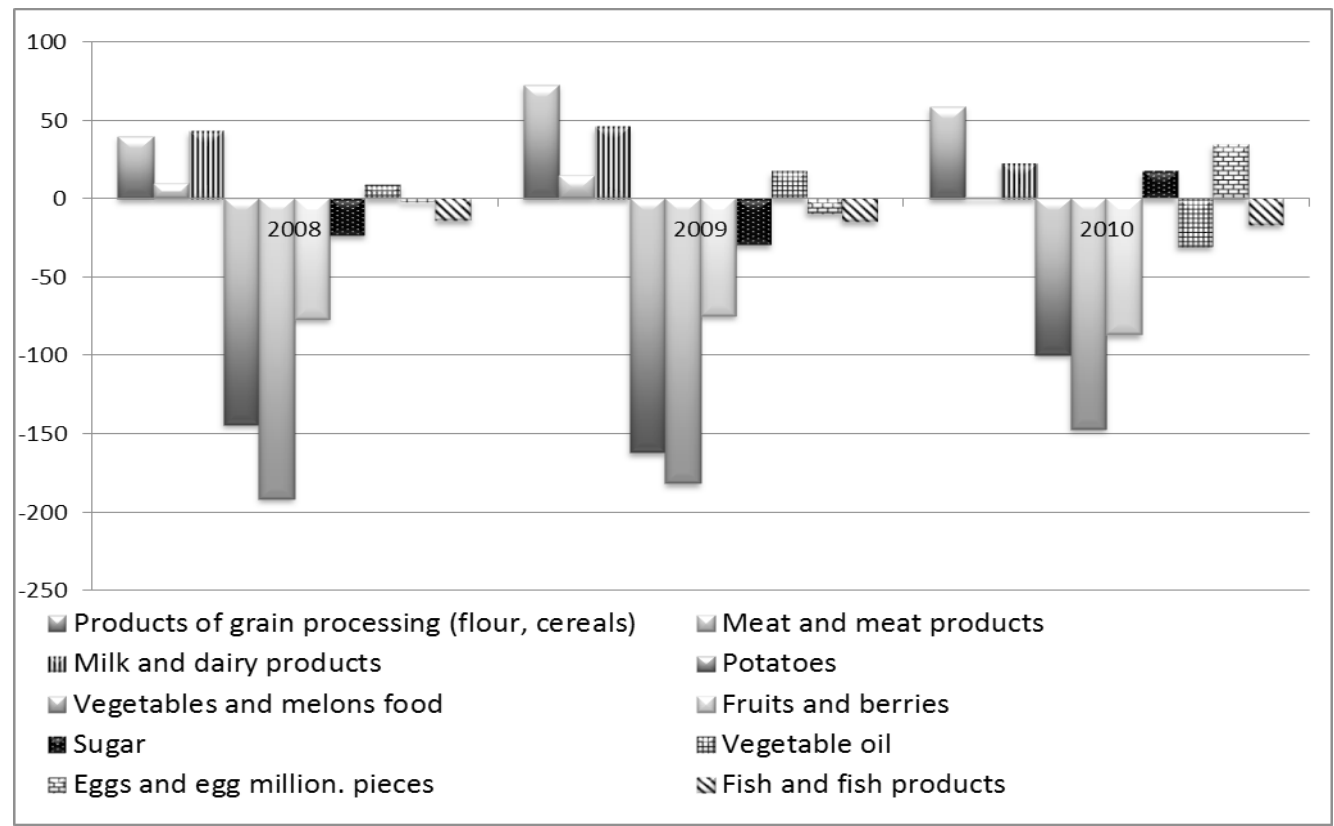

Source: Territorial Body of the Federal Service of State Statistics of the Russian Federation in Stavropol Krai, 2012

These data demonstrate that the products of grain processing, meat and meat products, milk and dairy products are commonly imported, while the supply of potatoes, vegetables, fruits and berries, eggs and egg products, sugar, fish and fish products are exported.

Despite the certain level of unsatisfied domestic needs, in 2012, the region exported $19 \%$ of vegetables, $11 \%$ of eggs, fruit, and sugar (Table 5). The main distribution channels for fruits and vegetables are the regions of the Central Federal District, for meat - the republics of the North Caucasus Federal District, for grain - other regions of Russia and foreign countries.

The significant scopes of counter deliveries of the same product groups are explained by the fact that the export of agricultural raw materials and low added value food imports advanced processing dominated in the balance of import-export products (Tables 4 and 5). It characterizes by the low level and significant reserves of the development of the food industry. 
Table 5. Export and import of basic foodstuffs by producing and wholesale organizations of the Stavropol Krai (in tons)

\begin{tabular}{|c|c|c|c|c|c|c|c|c|}
\hline \multirow{2}{*}{ 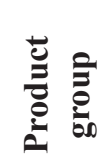 } & \multicolumn{2}{|c|}{2005} & \multicolumn{2}{|c|}{2009} & \multicolumn{2}{|c|}{2010} & \multicolumn{2}{|c|}{2011} \\
\hline & export & import & export & import & export & import & export & import \\
\hline 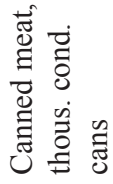 & $5,186.0$ & $1,010.0$ & $3,170.0$ & $2,126.0$ & 66.3 & 713.0 & $2,526.0$ & $1,014.0$ \\
\hline Meat & 465.0 & $16,914.0$ & 893.0 & $20,624.0$ & 902.0 & $22,577.0$ & 949.0 & $23,275.0$ \\
\hline Cheese & 499.0 & $1,487.0$ & $2,590.0$ & 510.0 & $1,361.0$ & $1,764.0$ & $1,606.0$ & 555.0 \\
\hline Butter & 316.0 & 471.0 & 691.0 & 887.0 & 362.0 & 650.0 & 970.0 & 772.0 \\
\hline Flour & $50,400.0$ & $3,800.0$ & $88,200.0$ & $1,400.0$ & 160.0 & 4.1 & 162.0 & 3.2 \\
\hline Cereals & $14,014.0$ & $1,447.0$ & $13,849.0$ & $1,629.0$ & $298,100.0$ & $62,100.0$ & $812,700.0$ & $117,400.0$ \\
\hline Sugar & $93,616.0$ & $31,578.0$ & $102,837.0$ & $20,922.0$ & $108,351.0$ & $36,562.0$ & $132,100.0$ & $42,782.0$ \\
\hline
\end{tabular}

Source: authors' development based on (Territorial Body of the Federal Service of State Statistics of the Russian Federation in Stavropol Krai, 2012)

The industrial and logistics infrastructure of the regional agricultural market are underdeveloped, which hampers manufacturers to manage their sales and promotion in an effective manner. The lack of storage facilities forces manufacturers to market their products during the very first months after harvesting, which means the lowest price. The absence of loading nodes prevents the creation of large quantities of products to participate in the exchange trade, export deliveries. As a result, the local market is not saturated, and agricultural producers receive less income.

The largest suppliers of agricultural and food products to the regional market are other regions of Russia and foreign countries. The share of imports in the foreign trade of Stavropol Region in the group of foodstuffs and agricultural raw materials for the last five years has been increasing from 16 to $39.5 \%$. Nevertheless, Stavropol region has trade surplus (Figure 4). In 2008, excess of exports over imports peaked (337 million USD) in 2013, the difference was 59.2 million USD. 
Figure 4. Trade balance of Stavropol Krai in the group of foodstuffs and agricultural raw materials

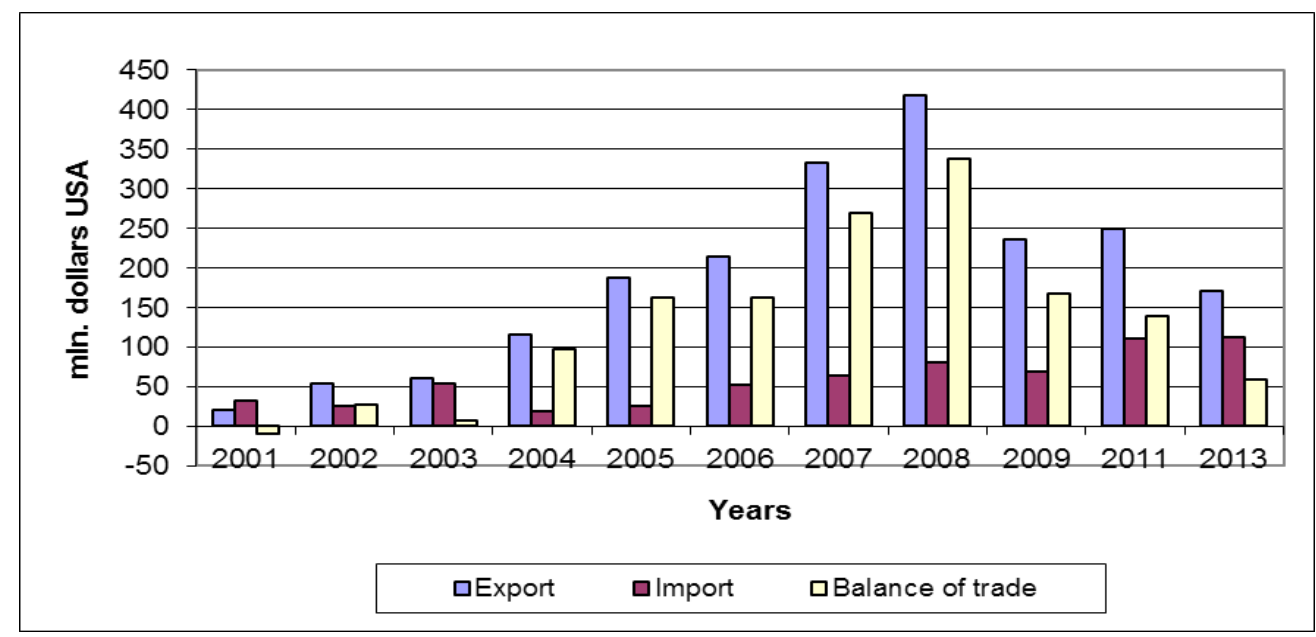

Source: authors' development based on (Territorial Body of the Federal Service of State Statistics of the Russian Federation in Stavropol Krai, 2013)

The export to CIS countries accounts for over $80 \%$ of foreign supplies and has steadily tendency to increase. The largest suppliers of regional food market are Egypt, Iran, Turkey, and Austria.

The main characteristic of the regional agri-food export is its high concentration on few commodities. Stavropol Krai traditionally sells wheat, including durum, barley, maize, wheat flour. Sunflower seeds, live sheep, greasy wool, poultry, and pasta are exported in small amounts and occasionally.

The so-called primary products dominate in exports. The outputs of refined products, ready-toeat, are insignificant. This leads to a conclusion that they are not competitive in the international market, and also points to the untapped potential of improving the competitiveness of regional agriculture through the development of the processing industry.

The important area of export expansion is the growing sector organic farming, including grain products. The demand for such products is now extremely high and, primarily, by the people of those countries which, because of limited natural resources, forced into ever more intensive farming methods and livestock breeding, concentrating the use of mechanization, application of chemicals and irrigation in a limited area, for example, the countries of the Southeast Asia.

Food products and raw materials are mainly imported from foreign countries (63\%); CIS countries account for $37 \%$ of shipments. The vegetables, fruits, meat and meat products, fish and fish products, alcoholic and non-alcoholic beverages are highlighted as the part of the import. 
Table 6. Share of imports in the formation of the main types of food resources (in \%)

\begin{tabular}{|l|c|c|c|c|c|c|}
\hline \multicolumn{1}{|c|}{ Groups of goods } & $\mathbf{2 0 0 8}$ & $\mathbf{2 0 0 9}$ & $\mathbf{2 0 1 0}$ & $\mathbf{2 0 1 1}$ & $\mathbf{2 0 1 2}$ & $\begin{array}{c}\text { Deviation of } \\
\mathbf{2 0 1 2} \text { by 2008, } \\
\text { percentage points }\end{array}$ \\
\hline Meat and meat products & 16.6 & 12.9 & 16.2 & 14.9 & 33.1 & 16.5 \\
\hline Milk and dairy products & 3.1 & 5.0 & 6.0 & 4.3 & 4.2 & 1.1 \\
\hline Potatoes & 29.3 & 32.1 & 20.8 & 21.4 & 16.1 & -13.2 \\
\hline Vegetables and melons food & 38.7 & 39.7 & 30.3 & 31.0 & 17.0 & -21.7 \\
\hline Fruits and berries & 44.7 & 45.1 & 47.2 & 45.8 & 46.9 & 2.2 \\
\hline Eggs and egg products & 12.7 & 10.9 & 6.7 & 17.1 & 22.9 & 10.2 \\
\hline Fish and fish products & 62.6 & 63.1 & 65.9 & 65.5 & 65.6 & 3.0 \\
\hline
\end{tabular}

Source: authors' development based on (Territorial Body of the Federal Service of State Statistics of the Russian Federation in Stavropol Krai, 2013)

The regional market is the most dependentfrom import of fruits (share of imports ranges from 44.7 to $46.9 \%$ ), and fish (over 65\%), (Table 7). In the dynamics observed a twofold reduction on import of potato and vegetables, essential uvelchenie on imports for meat (twofold), eggs (1.8 times), milk (from 3.1 to $4.2 \%$ ). During the past five years the import dependence has increased (meat 2.5 times, milk - by 1.4 times, eggs - by 1.7 times, eggs - by 10 percentage points). At the same time there was a significant reduction of import dependence in the consumption of potatoes and vegetables (Table 7).

Table 7. Share of imports in the consumption of basic foodstuffs (in \%)

\begin{tabular}{|l|r|r|r|r|r|r|}
\hline \multicolumn{1}{|c|}{ Groups of goods } & $\mathbf{2 0 0 8}$ & $\mathbf{2 0 0 9}$ & $\mathbf{2 0 1 0}$ & $\mathbf{2 0 1 1}$ & $\mathbf{2 0 1 2}$ & $\begin{array}{c}\text { Deviation of } \\
\text { 2012 by 2008, } \\
\text { percentage points }\end{array}$ \\
\hline Meat and meat products & 23.4 & 17.7 & 21.5 & 20.9 & 58.1 & 34.7 \\
\hline Milk and dairy products & 3.5 & 5.8 & 6.8 & 5.0 & 4.9 & 1.4 \\
\hline Potatoes & 36.0 & 39.2 & 24.0 & 26.1 & 20.1 & -15.9 \\
\hline Vegetables and melons food & 43.5 & 45.5 & 34.0 & 41.3 & 22.7 & -20.8 \\
\hline Fruits and berries & 52.6 & 52.6 & 55.6 & 53.8 & 55.3 & 2.7 \\
\hline Eggs and egg products & 14.7 & 12.2 & 7.5 & 18.8 & 25.3 & 10.6 \\
\hline Fish and fish products & 74.3 & 73.5 & 77.4 & 77.6 & 78.1 & 3.8 \\
\hline
\end{tabular}

Source: authors' development based on (Territorial Body of the Federal Service of State Statistics of the Russian Federation in Stavropol Krai, 2013)

It should be noted that the saturation of needs in food by their individual types is undervalued. The comparison of actual food consumption with evidence-based standards approved by the Ministry of Health and Social Development of the Russian Federation from 08.02.2010 "On approval of recommendations on rational norms of consumption of foods that meet the modern requirements of a healthy diet," suggests that the physiological needs of the population in milk, fish, fruits are satisfied less than $100 \%$. For milk the level of satisfaction of physiological needs is $-64 \%$, fish $-35 \%$ fruit $-39 \%$. The deficiency of these products is partly offset by excessive consumption 
of bread, vegetable oils and potatoes (Table 8). Thus, the consumption of bread exceeds the norm by $43 \%$, potatoes - by $23 \%$, vegetable oil - more than $70 \%$.

Table 8. Consumption of staple food per capita per year, Stavropol Krai (in kg/person)

\begin{tabular}{|l|r|r|r|r|r|r|r|}
\hline \multicolumn{1}{|c|}{ Types of products } & $\mathbf{2 0 0 0}$ & $\mathbf{2 0 0 5}$ & $\mathbf{2 0 0 9}$ & $\mathbf{2 0 1 0}$ & $\mathbf{2 0 1 1}$ & $\mathbf{2 0 1 2}$ & $\begin{array}{c}\text { Recommended } \\
\text { volumes }\end{array}$ \\
\hline $\begin{array}{l}\text { Meat and meat products } \\
\text { (including by-products } \\
\text { category II and fat, raw) }\end{array}$ & 39.0 & 48.0 & 61.0 & 65.0 & 67.0 & 73.0 & $70-75$ \\
\hline Milk and milk products & 175.0 & 188.0 & 191.0 & 206.0 & 206.0 & 210.0 & $320-340$ \\
\hline Vegetable oil & 13.5 & 14.5 & 16.3 & 17.2 & 19.0 & 19.1 & $10-12$ \\
\hline Bread and bakery products & 125.0 & 138.0 & 140.0 & 144.0 & 144.0 & 143.0 & $95-105$ \\
\hline Potatoes & 71.0 & 105.0 & 118.0 & 116.0 & 120.0 & 123.0 & $95-100$ \\
\hline Vegetables and melons food & 80.0 & 101.0 & 126.0 & 139.0 & 146.0 & 159.0 & $120-140$ \\
\hline Fruits and berries & 30.0 & 32.0 & 37.0 & 40.0 & 40.0 & 37.0 & $90-100$ \\
\hline Eggs, pieces & 226.0 & 252.0 & 270.0 & 287.0 & 290.0 & 295.0 & 260 \\
\hline Fish and fish products & 7.0 & 7.0 & 7.8 & 7.8 & 8.0 & 7.0 & $18-22$ \\
\hline Sugar & 42.0 & 51.0 & 53.0 & 54.0 & 55.0 & 50.0 & $24-28$ \\
\hline
\end{tabular}

Source: Territorial Body of the Federal Service of State Statistics of the Russian Federation in Stavropol Krai, 2013

The current pattern of consumption is determined by the degree of market saturation, economic availability of certain foods, and income level.

Calculations show that the average income per capita of the population in Stavropol Krai during the study period is below the average level. In 2012, it accounted for $73 \%$ of the Russia's average and 7-20\% lower than the revenue in the neighbouring regions (Table 9).

Table 9. Average income per capita of the population (in RUB per month)

\begin{tabular}{|l|r|r|r|r|r|r|r|r|}
\hline \multicolumn{1}{|c|}{ Region } & $\mathbf{2 0 0 0}$ & $\mathbf{2 0 0 5}$ & $\mathbf{2 0 0 8}$ & $\mathbf{2 0 0 9}$ & $\mathbf{2 0 1 0}$ & $\mathbf{2 0 1 1}$ & $\mathbf{2 0 1 2}$ & $\begin{array}{c}\text { The role played } \\
\text { in the Russian } \\
\text { Federation } \\
\mathbf{2 0 1 2}\end{array}$ \\
\hline $\begin{array}{l}\text { The Russian } \\
\text { Federation }\end{array}$ & 2,281 & 8,088 & 14,864 & 16,895 & 18,951 & 20,755 & 23,058 & $\mathbf{x}$ \\
\hline Stavropol Krai & 1,405 & 5,117 & 9,746 & 11,244 & 13,016 & 14,440 & 16,877 & 57 \\
\hline Krasnodar Krai & 1,563 & 5,545 & 11,906 & 13,752 & 16,892 & 18,796 & 21,077 & 27 \\
\hline Rostov region & 1,653 & 6,360 & 12,028 & 12,800 & 14,647 & 16,010 & 17,987 & 45 \\
\hline
\end{tabular}

Source: Federal Service of State Statistics of the Russian Federation

According to the level of cash income per capita Stavropol region occupies $62{ }^{\text {nd }}$ place in the country, while Krasnodar region $-25^{\text {th }}$, and Rostov region $-44^{\text {th }}$.

In an inflationary environment, the dynamics of the value of cash income is not sufficient to objectively reflect the change in the real level of material well-being of the population. To obtain more precise conclusions the ratio of cash income to subsistence level should be considered (Table 10). 
Table 10. Number of people with incomes below the subsistence level (in \%)

\begin{tabular}{|c|c|c|c|c|c|c|c|c|c|}
\hline Region & 2000 & 2005 & 2006 & 2007 & 2008 & 2009 & 2010 & 2011 & 2012 \\
\hline $\begin{array}{l}\text { The Russian } \\
\text { Federation }\end{array}$ & 29.0 & 17.8 & 15.2 & 13.3 & 13.4 & 13.0 & 12.5 & 12.7 & 10.9 \\
\hline Stavropol Krai & 45.2 & 24.9 & 22.1 & 19.1 & 20.2 & 19.7 & 18.5 & 18.3 & 14.0 \\
\hline Krasnodar Krai & 43.7 & 26.3 & 22.6 & 19.4 & 17.7 & 18.5 & 15.2 & 13.5 & 11.7 \\
\hline Rostov region & 33.1 & 18.3 & 18.5 & 16.0 & 14.9 & 16.0 & 14.9 & 15.2 & 13.1 \\
\hline
\end{tabular}

Source: Federal Service of State Statistics of the Russian Federation

These data suggest that the level of material well-being of residents of the territory for the past twelve years actually increased. The population with incomes below the annual increase, the subsistence level was reduced from $45.2 \%$ to $14 \%$. However, the proportion of poor people remains high and exceeds its share of the average in Russia and in neighbouring regions.

As the data in Table 11, indicates $70 \%$ of the territory's population have incomes up to 19 thousand RUB, while in the Russian Federation, their share is 55.6\%, in Krasnodar region $-60.2 \%$, and in Rostov region $-67 \%$.

Table 11. Distribution of population by capita income in 2012 (percentage of total population of the subject)

\begin{tabular}{|c|c|c|c|c|c|c|c|c|}
\hline \multirow[b]{2}{*}{ Region } & \multicolumn{8}{|c|}{ Per capita income (in RUB per month) } \\
\hline & $\begin{array}{r}\text { below } \\
5,000 \\
\end{array}$ & $\begin{array}{c}5,000 \\
-7,000 \\
\end{array}$ & $\begin{array}{c}7,000 \\
-\mathbf{1 0 , 0 0 0} \\
\end{array}$ & $\begin{array}{c}10,000 \\
-14,000 \\
\end{array}$ & $\begin{array}{c}14,000- \\
19,000\end{array}$ & $\begin{array}{r}19,000 \\
-\quad 27,000 \\
\end{array}$ & $\begin{array}{c}27,000 \\
-45,000\end{array}$ & $\begin{array}{c}\text { over } \\
45,000\end{array}$ \\
\hline $\begin{array}{l}\text { The Russian } \\
\text { Federation }\end{array}$ & 5.8 & 6.9 & 12.0 & 15.4 & 15.5 & 16.7 & 17.1 & 10.6 \\
\hline Stavropol Krai & 9.0 & 10.2 & 16.3 & 18.4 & 16.1 & 14.5 & 11.3 & 4.2 \\
\hline Rostov region & 8.5 & 9.5 & 15.3 & 17.7 & 16.0 & 15.1 & 12.6 & 5.3 \\
\hline Krasnodar Krai & 7.3 & 8.0 & 13.3 & 16.1 & 15.5 & 15.9 & 15.3 & 8.6 \\
\hline
\end{tabular}

Source: Federal Service of State Statistics of the Russian Federation

According to a sample survey of households, 35\% of the population of Stavropol Krai spends to the purchase of food. This means that in order to meet the needs of the population, agricultural-production markets of the territory should be largely focused on economically affordable products.

At the same time, the number of more affluent populations has steadily increased (Table 12). Thus, the proportion of people with incomes above 25,000 RUB has increased over the past five years, from $0.3 \%$ to $18.1 \%$. The income differentiation coefficient, calculated as the ratio of $20 \%$ of the wealthiest population to $20 \%$ of the less advantaged, for the last 8 years has increased from 11.7 to 13.1, indicating an increasing differentiation of income and is a signal for the expansion of market segments and better quality expensive food. 
Table 12. Distribution of the population of the Stavropol Krai according to their financial income

\begin{tabular}{|c|c|c|c|c|c|c|}
\hline \multirow{2}{*}{$\begin{array}{c}\text { Group with per capita } \\
\text { income per month, } \\
\text { RUB }\end{array}$} & \multicolumn{2}{|c|}{2005} & \multicolumn{2}{|c|}{2008} & \multicolumn{2}{|c|}{2012} \\
\hline & $\begin{array}{l}\text { thous. } \\
\text { people }\end{array}$ & $\begin{array}{l}\text { as percentage } \\
\text { of total }\end{array}$ & $\begin{array}{l}\text { thous. } \\
\text { people }\end{array}$ & $\begin{array}{l}\text { as percentage } \\
\text { of total }\end{array}$ & $\begin{array}{l}\text { thous. } \\
\text { people }\end{array}$ & $\begin{array}{c}\text { as percentage } \\
\text { of total }\end{array}$ \\
\hline below 2,000 & 412.7 & 15.1 & 80.8 & 2.9 & 12.2 & 0.4 \\
\hline $2,000-4,000$ & 937.0 & 34.2 & 420.4 & 15.2 & 125.1 & 4.5 \\
\hline $4,000-6,000$ & 616.3 & 22.5 & 517.0 & 18.7 & 250.2 & 9.0 \\
\hline $6,000-8,000$ & 337.5 & 12.3 & 442.0 & 16.0 & 302.5 & 10.8 \\
\hline $8,000-10,000$ & 182.8 & 6.7 & 337.7 & 12.2 & 301.4 & 10.8 \\
\hline $10,000-15,000$ & 179.1 & 6.5 & 499.5 & 18.1 & 620.2 & 22.3 \\
\hline $15,000-25,000$ & 65.2 & 2.4 & 336.2 & 12.3 & 671.4 & 24.1 \\
\hline over $25,000.0$ & 10.5 & 0.3 & 126.1 & 4.6 & 504.0 & 18.1 \\
\hline Population, total & $2,741.1$ & 100.0 & $2,759.7$ & 100.0 & $2,787.0$ & 100.0 \\
\hline $\begin{array}{l}\text { Income differentiation } \\
\text { coefficient (coefficient } \\
\text { of assets), times }\end{array}$ & & 11.7 & & 12.7 & & 13.1 \\
\hline
\end{tabular}

Source: authors' development based on (Territorial Body of the Federal Service of State Statistics of the Russian Federation in Stavropol Krai, 2013)

The suspension of imports exacerbates the problem of mobilizing all the potential to build up domestic food production. In the new circumstances, it is necessary to diversify the structure of production, to deepen its processing, to expand the range of final products, supplying the domestic market and beyond the territorywith goods with high added value. One of the immediate tasks in this regard is to create a full infrastructure for production, storage, marketing and processing of fruits and vegetables.

\section{Conclusions}

The key point among the strategic directions of development of the meat and dairysubcomplexesis takenby the concentration, specialization in livestock production and combination of large and small-scale production.

The greater importance is given to the development of the market of raw milk, which implies social, economic, financial, technical and technological, information and marketing support to all actors in this market (households in different categories).

Its strategic importance for the region will keep the grain market. To meet the growing domestic demand and stable export, substantial modernization of warehousing, transport infrastructure and logistics system - procurement, logistics, primarily elevator industry are needed. The urgency of this problem is related more to the fact that a large territory of the region is located in the zone of risky soil cultivating and years with good harvest alternate with barren, arid ones. In such a situation is of paramount importance possibility of long-term high-quality storage of large amounts of grain to guarantee the satisfaction of domestic and export commitments in the lean years.

The development and strengthening of their own brands is promising, for goods which are EP 2014 (61) 4 (877-893) 
imported from other regions will not be absolute substitutes from the consumer point of view; the development of the Stavropol brand in a foreign market by providing products of grain production, processing of poultry and vegetable oil.

Increasing the volume of sales may also be due to intra-differentiation of production into quality products targeting different (high, medium, low) levels of consumer income.

The increase in commodity products will contribute to the development of integration relations between subjects of agri-food market, a better use of the opportunities of cooperation. It is advisable to extend the coverage of sector unions, including the consolidation of the efforts of small producers, the development of a network of procurement, supply and marketing, processing and credit of agricultural consumer cooperatives.

In the light of the implementation of government objectives for import substitution in the region the program of priority measures for the development of agriculture, including raising additional funds from the federal budget was adopted. The program is aimed at improving the investment climate, business support, innovation, the development of an information network, providing state garanitees in the markets.

The implementation of these measures should, in the three-year period, significantly increase the production of agricultural products and foodstuffs, ensure food security, improve the balance of the food market of the territory and enhance the possibility of suppling to other regions of Russia.

\section{Literature}

1. Giovannucci, D., Scherr, S. J., Nierenberg, D., Hebebrand, C., Shapiro, J., Milder, J., Wheeler, K (2012): Food and Agriculture: The Future of Sustainability, Report for Rio+20, New York, USA, available at: http://peoplefoodandnature.org/publication/ food-and-agriculture-the-future-of-sustainability/

2. Erokhin, V., Ivolga, A. (2012): How to Ensure Sustainable Development of Agribusiness in the Conditions of Trade Integration: Russian Approach, International Journal of Sustainable Economies Management (IJSEM), vol. 1, no. 2, pp. 12-23.

3. Erokhin, V., Ivolga, A., Andrei, J. V., Cvijanović, D., Ion, R. A., Ivolga, I., Jeločnik, M., Labenko, O., Subić, J., Trukhachev, A., Turek Rahoveanu, A., Turek Rahoveanu, M. M., Vuković, P. (2014): Contemporary Issues of Sustainable Rural Development: International Approaches and Experiences of Eastern Europe and Russia, AGRUS of Stavropol State Agrarian University, Stavropol, Russia.

4. Erokhin, V., Ivolga, A., Heijman, W. (2014): Trade Liberalization and State Support of Agriculture: Effects for Developing Countries, Agric. Econ. - Czech, vol. 11, no. 60, pp. 524-537.

5. Federal Service of State Statistics of the Russian Federation, available at: http:// www.gks.ru/wps/wcm/connect/rosstat main/rosstat/ru/statistics/tariffs/ 
6. Hailu, M. B. (2010): Food Security and Agricultural Trade Liberalization, Proceedings from the conference - Second Biennial Global Conference, Barcelona, Spain.

7. Ivolga, I., Timofeeva, V. (2014): The analysis of the main tendencies of food security in the Russian Federation, Agricultural Bulletin of Stavropol Region, vol. 1, no. 13, pp. 70-73.

8. Jelocnik, M., Ivolga, A. (2012): International Approaches to Analysis of Regional Agricultural Potential: Cases of Stavropol Region and Republic of Serbia, Proceedings from the conference - Actual Problems of Agribusiness Development in the Conditions Economic Modernization, Stavropol, Russia, pp. 10-16.

9. Josling, T., Anderson, K., Schmitz, A., Tangerman, S. (2010): Understanding International Trade in Agricultural Products, One hundred years of contributions by agricultural economists, American Journal of Agricultural Economics, vol. 2, no. 92, pp. $424-446$.

10. Kiselev, S., Romashkin, R., Nelson, G. C., Mason - D’Croz, D., Palazzo, A. (2013): Russia 's food security and climate change: Looking into the future, Economics - The Open-Access, Open-Assessment E-Journal, no. 7, pp. 1-66.

11. On the application of certain special economic measures to ensure the security of the Russian Federation, the Decree of the President of the Russian Federation V. V. Putin, №560 from 06.08.2014.

12. Savkin, V., Pervykh, N. (2013): Food resources as the basis of the sustainable development and national security in the age of economic globalization, Visegrad Journal on Bio-economy and Sustainable Development, vol. 1, no. 2, pp. 28-33.

13. Serova, E. (2014): Food Security in Central Asia, portal of Russian international affairs council, available at: http://russiancouncil.ru/en/inner/?id 4=3777\#top

14. Stringer, R. (2000): Food Security in Developing Countries, CIES Working Paper, vol. 11., available at: http://www.adelaide.edu.au/cies/papers/0011.pdf

15. Territorial Body of the Federal Service of State Statistics of the Russian Federation in Stavropol Krai (2012): Agriculture of Stavropol Krai in 2005-2011. Statistical Bulletin of Stavropol Krai, Stavropolstat, Stavropol, Russia.

16. Territorial Body of the Federal Service of State Statistics of the Russian Federation in Stavropol Krai (2013): Brief Statistical Bulletin, Stavropolstat, Stavropol, Russia

17. Wegren, S. K. (2013): Food Security in the Russian Federation, Eurasian Geography and Economics, vol. 1, no. 54, pp. 22-41. 